\title{
Provenance of African-Born Individuals from the Colonial Cemetery of Campeche (Mexico) by Means of Trace Elements Analysis
}

\author{
Andrea Cucina ${ }^{1}{ }^{*}$, Hector Neff ${ }^{2}$, Vera Tiesler ${ }^{1}$ \\ ${ }^{1}$ Facultad de Ciencias Antropológicas, Universidad Autónoma de Yucatán \\ ${ }^{2}$ Department of Anthropology, California State University, Long Beach, CA (USA) \\ Universidad Autónoma de Yucatán, Mérida, Yucatán, México, 97000
}

ABSTRACT The present study investigates the issue of foreign provenance of African individuals buried in the early colonial cemetery of Campeche (Mexico) using multiple trace elements analysis from the first permanent molar. It rests on the assumption that, like for Strontium isotopes, the elemental pattern in the first molar reflects the hydro-geological environment the individual grew in. The individuals of African ethnicity were identified from their pattern of dental morphology. Twenty-eight individuals were analyzed in this context, eight of them supposedly Africans, while 15 were infants or early juveniles and five from the prehispanic site of Xcambó in northern Yucatán. The infants and juveniles were likely born in the area, thus serving as term of comparison for the |local" elemental pattern. The elements' ppm concentrations

The presence of African individuals in the colonial town of Campeche goes back to the 16th century AD when African slaves were brought in by the Spanish colonizers as servants and workers (Mallafe, 1973). Their presence in the ancient colonial cemetery in the town's Main Plaza (Plaza Principal) was initially suggested by a series of dental non-metric traits and particular dental decoration patterns, that were unknown to native Mesoamericans (Scott and Turner, 1997; Tiesler, 2001; Tiesler and Zabala, 2001). The cemetery surrounded the ancient church that was in use from the mid 16th century AD to the end of the 17th century, when it was replaced by Campeche's cathedral. The graveyard's chronology was confirmed by maps of the colonial town and by a medallion, whose typology is known not to have updated the 1650s (Coronel et al., 2001; Deagan, 2002). The material evidence confirms the historical sources that report the presence of Africans along with the arrival of the Spaniards (Mallafe, 1973). Apparently, Africans were employed as servants in the Spanish households (Zabala et al., 2003), as the production economy in the town of Campeche had no need for hardwork slavery, as in plantations or mines.

This study, which presents the preliminary results of an ongoing project on provenance in the Maya area during precontact and contact times, addresses the issue of the 28 individuals were elaborated using Principal Components Analysis. Results tend to cluster the infants and some of the African individuals together, though the majority of the Africans tend to group. One African individual in particular separates well from all the others. Assuming that dietary components might interfere with the individuals' distribution, only elements not related to diet were thus used, without different results from the previous analysis. Indeed, the elements correlating high with the first two components are non-dietary. Trace elements patterns indicate that some of the African individuals interred in the early colonial cemetery might have been born in other places, though we cannot infer on their place of origin, while others were probably born in the New World. Dental Anthropology 2004;17(3):65-69.

of detecting the place of nativity of Campeche's ethnic Africans. It assumes that trace element pattern from the enamel of the first molar reflects the environment the individuals were born in. For this reason, the persons who had been "imported" or had migrated from another area should present a pattern that differs from that of the local population (Cucina et al., 2004). In this context, the African individuals' pattern is compared to the one established from homologous teeth of infants recovered from the same site, resting on the assumption that babies buried in the cemetery were likely born in town or in its neighboring areas.

\section{MATERIALS AND METHODS}

The sample analyzed in this context is part of the skeletal collection of 180 individuals unearthed during the 2000 archaeological salvage excavation in the Plaza Principal of the town of Campeche, which is located long the coast of the Gulf of Mexico, in the northern part of the Yucatan Peninsula (Fig. 1). At least 20 skeletons showed

\footnotetext{
* Correspondence to: Andrea Cucina, Facultad de Ciencias Antropológicas, Universidad Autónoma de Yucatán, Calle 76 n. 455 LL 41 y 43, Col. Centro 9700, Mérida, Yucatán. E-mail: cucina@tunku.uady.mx
} 


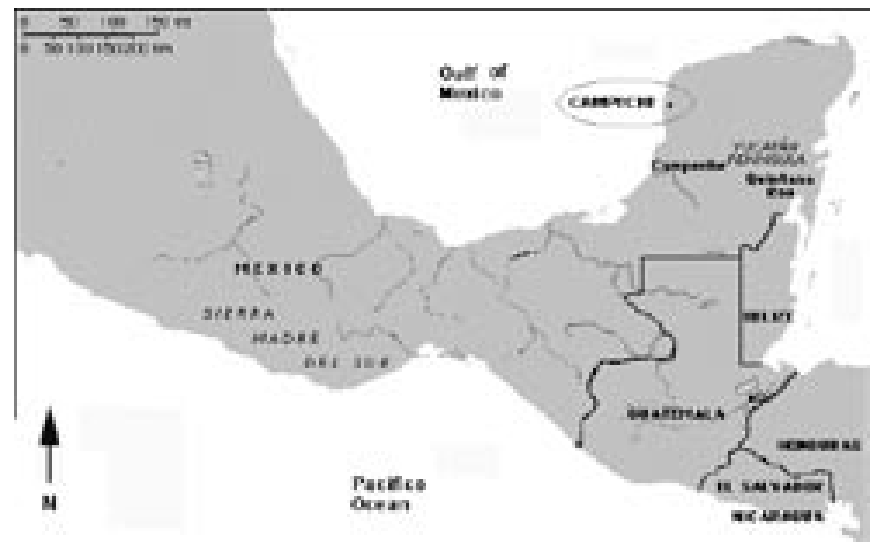

Fig. 1. Geographical location of the town of Campeche

a dental morphological pattern assignable to African ethnicity (Scott and Turner 1997; Irish 1997; 1998). Four of these individuals presented a pattern of dental mutilation unknown in the area during precolonial times (Tiesler, 2001) and similar to those introduced by African slaves throughout the Caribbean (Ortner, 1966; Handler et al., 1982; Milner and Larsen, 1991; Crespo, 1992).

The analysis was conducted on the first permanent molar of 28 individuals, eight of them showing African dental morphological patterns, 15 being infants and early juveniles that should be representative of the area. Five additional specimens come from the precontact Maya site of Xcambó. The choice of the first permanent molar rests on its age of development and the likeliness that it reflects more than other teeth the hydro-geological environment in which the individuals grew up (Molleson, 1988; Burton et al., 2003; Jones et al., 2003). The Africans are listed in the

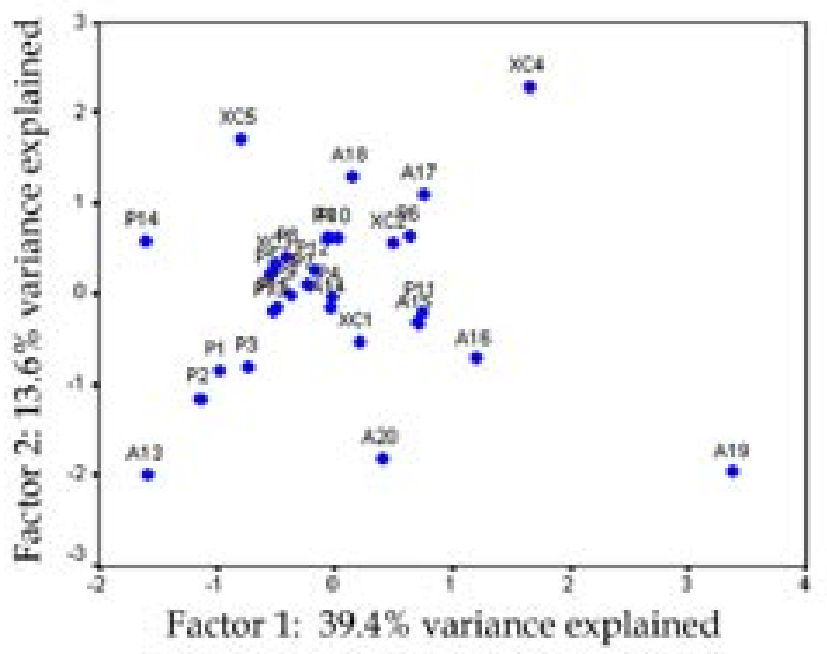

Fig. 2. Principal components analysis: distribution of the individuals along the first and second components using all the elements available (but Calcium) listed in Table 1. " $\mathrm{A}$ " labels the African individuals, " $\mathrm{P}$ " the autochthonous from Campeche, " $X$ " the individuals from the precontact, Classic site of Xcambó. graphs as " $\mathrm{A}$ " and a serial number ranging from 13 to 20. The Campeche infants are labeled as " $\mathrm{P}$ " and a serial number from 1 to 15 , while " $X C$ " (from 1 to 5 ) represents the individuals from Xcambó.

Teeth were sectioned longitudinally, and the inner layers of the "hidden enamel" (Hillson, 1996) exposed and analyzed by means of laser-ablation using a New Wave 213-nm laser and elements read by an ICP Perking Elmer 6100 DRC mass spectrometer. The elements' intensity was then transformed into parts per million (ppm), and converted into its $\log$ values for multivariate analyses.

\section{RESULTS}

The elements' intensity that was high enough to be read by the mass spectrometer was converted from ppm into logarithmic ones. Excluding calcium, these elements have been employed to perform principal components statistical analyses. Table 1 lists the elements' components rotated matrix, while Table 3 shows the same elements' components for the non-dietary elements only. The elements with higher values for each component appear in bold. Figure 2 shows the individuals' bi-dimensional scatter plot for first versus second components using all the elements available, while Figure 3 shows the same scatter plot after dietary elements were removed.

A common distribution pattern emerges from all the graphs, despite the wide range of variability in their elemental composition. The individuals identified as Africans tend to be more widely spread in all the graphs than the site's infants and young adolescents (labeled as P). Within the African group, some (A19 above all) constantly separate from the rest. Interestingly, we obtained the same pattern when we used all the elements or only the non-dietary ones.

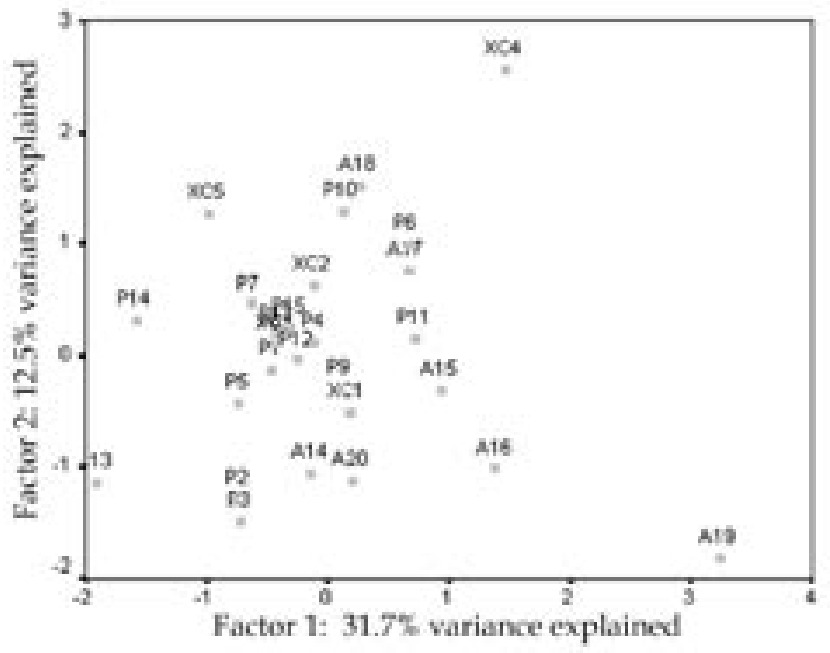

Fig. 3. Principal components analysis: distribution of the individuals along the first and second components using only non-dietary elements listed in Table 2. 
Table 1. Matrix of rotated components of all the elements analyzed ${ }^{1}$

\begin{tabular}{|c|c|c|c|}
\hline & 1 & 2 & 3 \\
\hline NA23 & 0.089 & 0.501 & -0.012 \\
\hline MG24 & -0.222 & 0.756 & -0.013 \\
\hline AL27 & 0.093 & 0.818 & 0.189 \\
\hline SI30 & 0.878 & -0.159 & 0.074 \\
\hline K39 & 0.164 & 0.483 & 0.241 \\
\hline SC45 & 0.098 & 0.003 & -0.032 \\
\hline TI47 & 0.101 & 0.448 & 0.364 \\
\hline V51 & -0.255 & -0.198 & -0.100 \\
\hline CR52 & 0.820 & -0.058 & 0.343 \\
\hline MN55 & 0.685 & 0.415 & 0.107 \\
\hline FE57 & 0.378 & 0.623 & 0.057 \\
\hline NI60 & 0.068 & 0.547 & 0.538 \\
\hline CU65 & 0.070 & -0.017 & 0.868 \\
\hline ZN66 & -0.455 & 0.091 & 0.009 \\
\hline AS75 & -0.115 & 0.411 & -0.011 \\
\hline RB85 & 0.571 & 0.261 & 0.583 \\
\hline SR88 & 0.000 & 0.102 & 0.217 \\
\hline ZR90 & 0.258 & 0.238 & 0.737 \\
\hline SB121 & -0.050 & -0.322 & -0.073 \\
\hline CS133 & 0.297 & 0.126 & 0.005 \\
\hline BA138 & 0.021 & 0.086 & 0.094 \\
\hline LA139 & 0.153 & 0.657 & 0.279 \\
\hline CE140 & 0.568 & 0.023 & 0.398 \\
\hline GD158 & 0.765 & 0.284 & 0.323 \\
\hline DY164 & 0.186 & 0.026 & -0.049 \\
\hline YB174 & 0.196 & -0.027 & 0.061 \\
\hline LU175 & 0.571 & 0.623 & 0.071 \\
\hline HF180 & -0.213 & 0.374 & 0.247 \\
\hline TA181 & 0.249 & 0.437 & 0.213 \\
\hline PB208 & 0.275 & 0.213 & 0.725 \\
\hline TH232 & 0.720 & 0.130 & -0.072 \\
\hline U238 & 0.068 & 0.136 & 0.460 \\
\hline
\end{tabular}

${ }^{1}$ Varimax rotation converged in 20 iterations. Values in bold indicate the elements.

\section{DISCUSSION}

Historical sources report the presence of African slaves in Campeche since the arrival of the Spanish (Scholes, 1936; Redondo, 1995). Their presence in the catholic cemetery is not unusual, as they were converted to the catholic religion upon arrival (Aguirre Beltrán, 1994). Therefore, we expect that the African population in the cemetery of the town's Plaza Principal may be representative of persons born both in the Old and in the New World.

Trace elements have been used to detect foreign provenance within archaeological samples (Burton et al., 2003; Jones et al., 2003), despite their broader range of variability and less stability when compared to stable isotopes. Trace elements are subject to dietary and physiological influence, as well as diagenetic changes
Table 2. Component's rotated matrix of the non-dietary elements. Varimax rotation converged in 7 iterations $^{1}$

\begin{tabular}{lrrr}
\hline & 1 & \multicolumn{1}{c}{2} & \multicolumn{1}{c}{3} \\
\hline AL27 & 0.041 & 0.868 & 0.208 \\
SI30 & 0.910 & -0.117 & 0.007 \\
SC45 & 0.133 & 0.045 & -0.045 \\
TI47 & 0.043 & 0.638 & 0.391 \\
V51 & -0.252 & -0.047 & -0.075 \\
CR52 & 0.845 & 0.092 & 0.296 \\
NI60 & 0.013 & 0.538 & 0.647 \\
CU65 & 0.056 & 0.017 & 0.925 \\
AS75 & -0.084 & 0.603 & -0.132 \\
RB85 & 0.525 & 0.254 & 0.668 \\
ZR90 & 0.311 & 0.309 & 0.597 \\
SB121 & -0.105 & -0.057 & -0.009 \\
CS133 & 0.178 & 0.302 & 0.131 \\
LA139 & 0.122 & 0.735 & 0.257 \\
CE140 & 0.540 & 0.055 & 0.463 \\
GD158 & 0.819 & 0.213 & 0.247 \\
DY164 & 0.160 & 0.109 & -0.001 \\
YB174 & 0.195 & 0.045 & 0.083 \\
LU175 & 0.532 & 0.672 & 0.042 \\
HF180 & -0.117 & 0.414 & 0.126 \\
TA181 & 0.229 & 0.421 & 0.230 \\
PB208 & 0.354 & 0.253 & 0.642 \\
TH232 & 0.689 & 0.076 & 0.016 \\
U238 & 0.046 & 0.195 & 0.486 \\
\hline
\end{tabular}

${ }^{1}$ Values in bold indicate the elements.

(Sandford and Weaver, 2000), which may affect the hydro-geological marks left by the environment during growth (Molleson, 1988). Interestingly the results from this study bestow similar patterns regardless whether all the elements or only the non-dietary elements were used in teeth. Apparently, this indicates that neither diet nor diagenesis affect the elemental pattern from first molar's hidden enamel. The elements that show higher correlation values with each component are not the "dietary" ones, and if diagenesis had altered the chemical composition, results should have been flattened and more homogeneity should have been found.

The results indicate that some of the ethnic African individuals from Campeche's colonial cemetery may not have been born in the area, in particular the individual labeled as A19 and to a lesser extent A16, A20 and A15. Previous analyses on other batches of trace elements readings (Cucina, 2004; Cucina et al., 2004) still indicated an African individuals' distribution pattern almost independent from the native one. A16 and A15 showed a kind of dental decoration unknown in precolonial Mesoamerica (Tiesler, 2001) and apparently imported from the African continent. At this point of the analysis it appears that the decorated individuals were born outside Campeche, although we cannot make specific 
inferences on whether these individuals had undergone the process when still in their country of origin or whether this practice was introduced and performed in Yucatán at least for a generation or two before disappearing. Further analyses and confirmation of nativity from stable isotopes on the same individuals will help us better understand this complex multiethnic society in colonial times.

In conclusion, trace elements provided promising results in detecting foreigners in archaeological samples. Differently from previous studies that focused on one or two elements, this analysis uses a multi-elements approach. The application of laser ablation permits to spot-read the hidden enamel, limiting the effects of diagenesis. Some individuals were not likely born in the area, although it is not yet possible to detect whether their place of origin was Africa or somewhere in the Caribbean or Mesoamerica, for an African comparison pattern in not available, the exact date of death is unknown (no tombstone or parish record) and the time span the cemetery was in use encompasses two centuries. Notwithstanding these limitations and the problems in obtaining consistent data due to calibration of the equipment, this analysis indicates that trace elements can find applications in studies of natality and migration patterns.

\section{ACKNOWLEDGMENTS}

The authors want to thank Dr. P. Zabala for sharing the historical information on Campeche's ethnic integration, the State of Campeche and the INAH Campeche for institutional support. A special thanks goes to Sachiko Sakai for helping us with the laser. The research has been funded by PROMEP grant $n$. 103.5/03/1125.

\section{LITERATURE CITED}

Aguirre Beltrán G. 1994. El negro esclavo en Nueva España. La formación colonial, la medicina popular y otros ensayos. Fondo de Cultura Económica, México: 110.

Burton JH, Price TD, Cahue L, Wright LE. 2003. The use of barium and strontium abundances in human skeletal tissues to determine their geographic origins. International J Osteoarch 13:88-95.

Coronel G, Cortés G, Osnaya K, Cybele D, Tiesler V, Zabala P. 2001. Prácticas funerarias e ideosincracia en la ciudad colonial de Campeche. Los Investigadores de la Cultura Maya, 9:197-206.

Crespo Torres E. 1992. Primera evidencia de mutilación dentaria en una población negroide de Puerto Rico. Revista Salud y Cultura, Universidad de Puerto Rico, San Juan, Año 4, 1:95-105.

Cucina A. 2004. Procedencia y estatus social de los africanos en la villa colonial de Campeche: un estudio químico y antropológico preliminar. Estudios de Antropologia Biologicas, 12 (in press).

Cucina A, Neff H, Tiesler V. 2004. Detecting provenience of African-origin individuals in the colonial cemetery of Campeche (Yucatán): a new approach using trace elements and LA-ICP-MS. In: Speakman RJ, Neff H, editors. Applications of LA-ICP-MS in archaeology. Albuquerque: University of New Mexico Press (in press).

Deagan K. 2002. Artifacts of the Spanish colonies of Florida and the Caribbean, 1500-1800. Vol. 2: Portable personal possessions. Washington, DC: Smithsonian Institution.

Handler JS, Corruccini RS, Mutaw RJ. 1982. Tooth mutilation in the Caribbean: evidence from slave burial population in Barbados. J Hum Evol 11:297313.

Hillson S. 1996. Dental anthropology. Cambridge: Cambridge University Press.

Irish JD. 1997. Characteristic high- and low-frequency dental traits in sub-Saharan African populations. Am J Phys Anthropol 102:455-467.

Irish JD. 1998. Ancestral dental traits in recent subSaharan Africans and the origins of modern humans. J Hum Evol 34:81-98.

Jones J, Goodman AH, Reid J, Amarasiriwardena D, Mack ME, Blakey ML. 2003. Permanent molars and shifting landscapes: elemental signature analysis of natality at the New York African Burial ground. Am J Phys Anthropol 120 S36:124.

Mallafe R. 1973. Breve historia de la Esclavitud en América Latina. Secretaría de Educación Pública, México.

Milner GR, Larsen CS. 1991. Teeth as artifacts of human behavior: intentional mutilation and accidental modification. In: Kelley MA, Larsen CS, editors. Advances in dental anthropology. New York: WileyLiss, $\mathrm{p}$ 357-378.

Molleson T. 1988. Trace elements in human teeth. In: Grupe G, Herrmann B, editors. Trace elements in environmental history. Berlin: Springer-Verlag, p 6782.

Ortner DJ. 1966. A Recent occurrence of an African type tooth mutilation in Florida. Am J Phys Anthropol 25: 177-180.

Redondo B. 1995. Negritud en Campeche. De la conquista a nuestros días. In: Martínez Montiel LM, editor. Presencia Africana en México. México. Consejo Nacional para la Cultura y las Artes. p 353.

Sandford MK, Weaver DS. 2000. Trace Element Research in Anthropology: New Perspectives and Challenges. In: Katzenberg MA, Saunders SR, editors. Biological anthropology of the human skeleton. New York: Wiley-Liss, p 329-350.

Scholes FV. 1936. Documentos para la Historia de Yucatán. 1550-1561. Mérida.

Scott RG, Turner II CG. 1997. The anthropology of modern teeth: dental morphology and its variation in recent human populations. Cambridge: Cambridge University Press. 
Tiesler V. 2001. Short report: new case of an African tooth decoration from colonial Campeche, Mexico. Homo 52:277-282.

Tiesler V, Zabala P. 2001. Reflexiones sobre la composición poblacional del estado de salud y las condiciones de vida vigentes en la ciudad de Campeche durante los siglos XVI y XVII. Los Investigadores de la Cultura Maya 9:197-206.

Zabala P, Cucina A, Tiesler V, Neff H. 2003. La población africana en la villa colonial de Campeche: un estudio interdisciplinario. Los Investigadores de la Cultura Maya, 12 (in press).

\section{Dental Anthropology Association Celebrates Its 20th Meeting}

In celebration of its 20th meeting, the Dental Anthropology Association is sponsoring a symposium at the 2005 American Association of Physical Anthropologists meetings to be held in Milwaukee, Wisconsin. Dental Anthropology 20 Years After: The State of the Science will consist of 14 papers covering a wide range of topics germane to the anthropological study of teeth. Organized and chaired by DAA Past President Joel Irish (Alaska, Fairbanks) and Greg Nelson (Oregon) the symposium brings together a myriad of researchers for a welcome look at the relevance and breadth of Dental Anthropology as it stands in the middle of the first decade of the 21st century. The Symposium is scheduled as Session 9 on Thursday afternoon April 7. This is fortuitous, as the symposium precedes the annual DAA business meeting scheduled for Thursday evening. We expect everyone to attend.

In addition to the symposium, dental anthropology will be well represented at the 2005 AAPA meetings with a podium session (session 3, Thursday morning) and a poster session (session 26, Saturday morning) scheduled. Following is the symposium abstract and a list of authors and paper titles:

\section{Dental Anthropology 20 Years After: The State of the Science}

Organizers and Chairs: Joel D. Irish, University of Alaska Fairbanks, and Greg C. Nelson, University of Oregon.

Commemorating the 20th anniversary meeting of the Dental Anthropology Association, this symposium highlights recent research in the subfield that is illuminating issues of fundamental anthropological importance. Using both established and innovative new methodological and technological approaches, scholars with interests ranging from the micro- to macroscopic levels of structure and expression present their latest findings on dental genetics, histology, growth and development, pathology, and morphometrics across a broad range of living and fossil human and non-human primate taxa. Thus, unlike many symposia that focus on specific topics and/or regions, the unifying theme here is diversity. The intent is to assess the current state of the subfield, emphasize its insights into diverse anthropological questions, and explore its potential future directions. Cosponsored by the Dental Anthropology Association.

Leslea Hlusko and Michael C. Mahaney. Conceptualizing dental characters: Implications from baboon quantitative genetic analyses.

Gary Schwartz. The evolutionary history of growth and development: Sorting through the evidence with a fine tooth-comb.

Helen Liversidge. Dental age revisited.

Debbie Guatelli-Steinberg. Using perikymata to estimate the duration of growth disruptions in fossil hominin teeth.

Louise Humphrey, Christopher Dean, and Teresa Jeffries. Identification of the neonatal line using LAICP-MS.

Mark Teaford. Insights from life's little abrasions: Dental microwear at middle-age.

Peter Ungar and Sarah Taylor. Dental topographic analysis: Tooth wear and function.

Simon Hillson. The current state of dental decay.
Brian Hemphill. At what cost a full belly? An investigation of the seductive allure of sedentary horticulture in the Great Basin.

Kalpana Agrawal and Peter Lucas. Methods of ingestion and incisal designs.

Shara Bailey. The place of Neandertals in modern human evolution: Intra- and interspecific variation in occlusal dental morphology.

Charles FitzGerald and Simon Hillson. Dental reduction in late Pleistocene and early Holocene hominids: Alternative approaches to assessing tooth size.

Roberto Macchiarelli and Luca Bondioli. Virtual dentitions: Touching the hidden evidence.

Discussants for the Symposium: John Luckas and Edward Harris.

Submitted by: Greg C. Nelson 